\title{
PENGARUH PENAMBAHAN TEPUNG DAUN INDIGOFERA ZOLLINGERIANA DALAM RANSUM TERHADAP PRODUKSI DAN BERAT TELUR AYAM ARAB
}

\author{
Muhammad Amrullah Pagala ${ }^{1}$, Ali Bain ${ }^{1}$, Asis Surajat ${ }^{2}$ \\ ${ }^{1}$ Dosen Program Studi Peternakan PPs UHO \\ ${ }^{2}$ Alumnus Program Studi Peternakan PPs UHO \\ Email : amrullah.pagala@uho.ac.id
}

\begin{abstract}
This study aimed to evaluate the effect of using leaf flour of Indigofera zollingeriana which was added to the ration on the productivity and quality of Arab chicken eggs. This research conducted in March to May of 2018. This research conducted at the Permata Poultry Farm Group in Wua Wua Village, Kendari. This research used a completely randomized design with four (4) treatments and four (4) replications. The experimental ration which was tested consisted of: $\mathrm{P} 0=$ The Ration contained $0 \%$ Indigofera leaf flour, P1 = ration containied 10\% Indigofera leaf flour, P2 = Ration contained 15\% Indigofera leaf flour, and P3 $=$ Ration contained 20\% Indigofera leaf flour. The parameters were observed feed consumption, egg weight, feed conversion, daily egg production. The research data were analyzed by using Analysis of Variance (ANOVA) based on RAL in using Statistical Product and Service Solutions (SPSS) software. If the treatment has a significant effect, further testing will be carried out with the Duncan Multiple Range Test. The results of this study showed that the addition leaf flour of indigofera zollingeriana in Arab chicken rations affected the feed conversion and egg weight of Arabic chicken, however indigofera leaf flour did not affect the feed consumption and egg production of Arab chicken
\end{abstract}

Keywords: Indigofera Zollingeriana, Feed conversion, Egg Production, Arabic Chicken.

\begin{abstract}
ABSTRAK
Penelitian ini bertujuan untuk mengevaluasi pengaruh penggunaan tepung daun Indigofera zollingeriana yang ditambahkan dalam ransum terhadap produktivitas dan kualitas telur ayam arab. Penelitian ini dilakukan pada Bulan Maret sampai dengan Mei Tahun 2018. Penelitian ini dilakukan di Lokasi Kelompok Peternakan Unggas Permata Kelurahan Wua- wua, Kendari. Penelitian ini menggunakan Rancangan Acak Lengkap dengan 4 (empat) perlakuan dan 4 (empat) ulangan. Ransum percobaan yang diuji adalah terdiri atas: P0 $=$ Ransum mengandung $0 \%$ Tepung daun Indigofera, $\mathrm{P} 1=$ Ransum mengandung 10\% Tepung daun Indigofera, P2 = Ransum mengandung 15\% Tepung daun Indigofera, dan P3 = Ransum mengandung 20\% Tepung daun Indigofera. Parameter yang diamati adalah konsumsi pakan, berat telur, konversi pakan, produksi telur harian. Data penelitian dianalisis menggunakan analisis ragam (ANOVA) berdasarkan RAL menggunakan software Statistical Product and Service Solutions (SPSS). Apabila perlakuan berpengaruh nyata maka dilakukan uji lanjut dengan Uji Duncan Multiple Range Test. Berdasarkan hasil penelitian disimpulkan bahwa tepung daun Indigofera zollingeriana dapat mempengaruhi berat telur ayam arab dan konversi pakan ayam arab. Namun tidak mempengaruhi konsumsi pakan ayam arab dan produksi telur harian ayam arab
\end{abstract}

Kata kunci : Indigofera zollingeriana, Konversi Pakan, Produksi telur, Ayam arab. 


\section{PENDAHULUAN}

Ayam arab merupakan salah satu jenis ayam petelur bukan ras yang memiliki prospek pasar yang baik untuk dikembangkan di Indonesia. Produksi telurnya relatif tinggi hampir menyerupai produktivitas ayam ras petelur yaitu sekitar $190-250$ butir pertahun. Karakteristik telurnya menyerupai telur ayam lokal dengan bobot telur sekitar 39-42 g dan hampir tidak memiliki sifat mengeram sehingga waktu bertelur menjadi lebih panjang (Sulandari et al, 2007).

Produksi telur ayam arab yang baik dapat dicapai ketika kebutuhan nutrien dalam pakan tercukupi. Pakan yang baik merupakan pakan yang memiliki kandungan nutrien yang sesuai dengan kebutuhan ternak yang akan dipelihara. Produksi telur yang baik dipengaruhi oleh bahan pakan yang digunakan sebagai pakan ayam arab. Bahan pakan yang baik dapat meningkatkan produktivitas dan kualitas telur. Salah satu bahan pakan yang memiliki kandungan nutrien yang baik yaitu daun Indigofera zollingeriana.

Tanaman Indigofera zollingeriana merupakan tanaman yang memiliki produktivitas hijauan cukup tinggi dan kandungan nutrien cukup baik, terutama kandungan proteinnya cukup tinggi. Menurut Abdullah (2010), kandungan protein kasar yang terdapat pada daun indigofera mencapai 29,16\%, serat kasar mencapai 14,02\%, dan lemak kasar mencapai 3,62\%. Daun Indigofera zollingeriana dapat meningkatkan konsumsi pakan, bobot telur, produksi telur, massa telur, konversi pakan, skor kuning telur, serta menurunkan kandungan kolesterol telur puyuh dan kadar malondyaldehide (MDA). Kandungan $ß$-karoten tepung pucuk indigofera dapat meningkatkan kandungan vitamin A telur burung puyuh (Faradillah, 2015). Dilihat dari kandungan nutrien dan fungsinya, maka daun Indigofera zollingeriana, dapat digunakan sebagai bahan pakan unggas, Berdasarkan hal tersebut dilakukan penelitian penambahan tepung daun Indigofera zollingeriana dalam pakan ayam arab untuk mengetahui apakah tepung daun Indigofera zollingeriana dapat mempengaruhi produksi dan kualitas telur ayam arab. Penelitian ini bertujuan untuk mengevaluasi pengaruh penggunaan tepung daun Indigofera zollingeriana yang ditambahkan dalam pakan terhadap produktivitas dan kualitas telur ayam arab.

\section{MATERI DAN METODE}

\section{Waktu dan Tempat}

Penelitian ini dilakukan pada bulan Maret sampai dengan Mei Tahun 2018. Pemeliharaan ayam arab dilakukan di Lokasi Kelompok Peternakan Unggas Permata Kelurahan Wua-wua, Kendari, analisis kandungan nutrisi bahan pakan dilakukan di Laboratorium Ilmu dan Teknologi Pakan Institut Pertanian Bogor.

\section{Materi Penelitian}

Penelitian ini menggunakan 32 ekor ayam arab betina berumur 6 bulan. Ayam arab diperoleh dari Kota Kediri Provinsi Jawa Timur. Bobot ayam arab yang digunakan memiliki rata-rata $1,10 \mathrm{~kg} \pm 0,05$, dan warna bulu yang sama yaitu silver.

Alat yang digunakan pada penelitian adalah kandang baterai dengan ukuran 40 $\mathrm{cm}$ x $30 \mathrm{~cm}$ x $30 \mathrm{~cm}$, yang dilengkapi dengan tempat pakan dan tempat air minum ayam, timbangan digital, Perangkat peralatan laboratorium untuk menganalisis kandungan nutrien daun indigofera, serta peralatan tulis menulis.

Pakan penelitian diberikan dalam bentuk pellet dengan nutrien pakan yaitu: protein kasar: $18 \%$, energi metabolis: 3.000 - $3.100 \mathrm{kkal} / \mathrm{kg}$, lemak: 6,2\%, dan serat kasar: 9,8\%. Kandungan nutrien pakan didasarkan kepada kebutuhan ayam arab 
fase produksi telur. Bahan pakan yang digunakan untuk menyusun pakan ayam arab fase produksi telur yaitu: daun Indigofera zollingeriana, dedak padi, jagung giling, dan RK-24. Daun Indigofera zollingeriana diperoleh dari lahan peternakan di Desa Wawolemo, dedak padi dan jagung diperoleh dari Kecamatan Konda, sementara RK-24 yang digunakan diperoleh dari toko pertanian dan peternakan. Bahan pakan yang digunakan, terlebih dahulu dianalisis kandungan nutriennya sebagai dasar penyusunan ransum penelitian.

\section{Metode Penelitian}

\section{Penyiapan Pakan Perlakuan}

a. Pembuatan tepung daun Indigofera zollingeriana

Daun Indigofera zollingeriana yang digunakan dalam penelitian ini diambil dari Desa Wawolemo. Daun Indigofera zollingeriana yang dipanen kemudian diolah menjadi tepung. Daun Indigofera zollingeriana sebelum dijadikan tepung, terlebih dahulu dikeringkan di bawah cahaya matahari. Setelah daun Indigofera zollingeriana kering, selanjutnya digiling sampai daun Indigofera zollingeriana menjadi tepung. Tepung daun Indigofera zollingeriana sebelum digunakan, terlebih dahulu dianalisis kandungan nutriennya untuk penyusunan ransum sesuai perlakuan.
Pembuatan tepung daun Indigofera zollingeriana dilakukan dengan beberapa tahapan:

1. Daun Indigofera zollingeriana segar dipanen dari perkebunan, yang diambil adalah bagian daun yang masih muda.

2. Daun yang telah diambil dianginanginkan tanpa terkena matahari secara langsung selama \pm 1 hari agar daun tidak berubah warna.

3. Setelah diangin-anginkan daun dijemur dengan cahaya matahari selama \pm 10 jam, kemudian digiling hingga berbentuk tepung.

b. Analisis kandungan nutrien bahan pakan Tepung daun Indigofera zollingeriana, dedak padi, jagung giling, dan kosentrat terlebih dahulu dianalisis kandungan nutrisinya agar dapat diketahui kandungan nutriennya. Analisis kandungan nutrien tepung daun Indigofera zollingeriana, dedak padi, jagung giling, dan kosentrat dianalisis kandungan nutriennya di Laboratorium Ilmu Nutrisi dan Teknologi Pakan Institut Pertanian Bogor.

c. Komposisi Bahan dan Kandungan Nutrien pakan Perlakuan

Formulasi ransum dilakukan untuk memenuhi kebutuhan ayam arab fase produksi. Komposisi nutrien bahan pakan yang digunakan pada penelitian ini disajikan pada Tabel 1 Persentase pemberian beberapa jenis bahan pakan dan kandungan nutrien yang diberi pada ayam arab dapat dilihat pada Tabel 2

Tabel 1. Komposisi nutrien bahan pakan penelitian

\begin{tabular}{lllll}
\hline \multirow{3}{*}{ Bahan pakan } & \multicolumn{4}{l}{ Kandungan nutrien bahan pakan } \\
\cline { 2 - 5 } & $\begin{array}{l}\text { Protein kasar } \\
(\%)\end{array}$ & $\begin{array}{l}\text { Lemak } \\
(\%)\end{array}$ & $\begin{array}{l}\text { Energi } \\
(\mathrm{kkal} / \mathrm{kg})\end{array}$ & Metabolis \\
\hline Indigofera & 25,66 & 3,78 & 2900 & Serat Kasar $(\%)$ \\
Dedak & 11,20 & 13,51 & 2400 & 12,15 \\
Jagung & 8,50 & 2,32 & 3300 & 10,44 \\
RK-24 & 28,25 & 2,39 & 3500 & 8,82 \\
\hline
\end{tabular}

Keterangan: Komposisi nutrien bahan pakan Daun indigofera, Jagung, RK-24 dan dedak hasil analisis Laboratorium Ilmu dan Teknologi Pakan IPB. 
Tabel 2. Komposisi bahan pakan dan kebutuhan nutrien penelitian

\begin{tabular}{lllll}
\hline Bahan pakan & \multicolumn{4}{c}{ Perlakuan } \\
\cline { 2 - 5 } & P0 & P1 & P2 & P3 \\
\hline Jagung (\%) & 19 & 22 & 24 & 25,7 \\
Dedak (\%) & 38,1 & 33,1 & 30 & 27,3 \\
Kosentrat(\%) & 42,9 & 34,9 & 31 & 27 \\
Tepung daun indigofera (\%) & 0 & 10 & 15 & 20 \\
\hline Total (\%) & 100 & 100 & 100 & 100 \\
\hline Kandungan nutrien : & & & & \\
Protein Kasar (\%) & 18,00 & 18,00 & 18,00 & 18,00 \\
Lemak (\%) & 6,61 & 6,19 & 5,91 & 5,69 \\
Energi Metabolis (kkal/kg) & 3042,9 & 3031,9 & 3032 & 3028,30 \\
Serat Kasar (\%) & 9,27 & 9,55 & 9,68 & 9,82 \\
\hline Kenyyyyy
\end{tabular}

Keterangan: Metode penyusunan ransum perlakuan menggunakan metode trial and error.

\section{Kandang Penelitian}

Kandang yang digunakan adalah jenis kandang individu sebanyak 32 petak kandang. Ukuran kandang $40 \mathrm{~cm}$ x $30 \mathrm{~cm}$ x $30 \mathrm{~cm}$, untuk 1 ekor ayam arab. Setiap petak kandang dilengkapi dengan 1 tempat minum dan 1 tempat pakan. Tempat pakan terbuat dari pipa berukuran 2,5 inchi yang dibelah menjadi dua bagian. Tempat pakan diletakan di luar petak kandang. Tempat minum ayam diletakan 1 unit setiap 1 petak kandang. Kandang yang digunakan diletakan pada satu ruangan yang dilengkapi dengan lampu pijar 20 watt. Sebelum ayam dimasukan dalam kandang, kandang disanitasi terlebih dahulu dengan desinfektan demikian pula tempat makan dan minum.

\section{Aplikasi pakan Perlakuan}

a. Penempatan ayam dalam kandang

Ayam arab berjenis kelamin betina yang berumur 180 hari (6 bulan) terlebih dahulu diseleksi agar dapat diketahui berat dari masing-masing induk ayam. Ayam arab yang digunakan adalah ayam arab betina yang memiliki berat yang homogen dan warna relatif sama yaitu $1,1 \mathrm{~kg} \pm 0,05$. Setelah diketahui berat masing-masing ayam, maka ayam dimasukan ke dalam kandang yang telah disediakan untuk diberikan ransum perlakuan. b. Pemberian pakan perlakuan dan air minum

Pakan perlakuan yang diberikan pada penelitian ini adalah campuran beberapa jenis bahan pakan yang telah ditentukan komposisinya termasuk tepung daun indigofera. Aplikasi pakan perlakuan dilakukan selama 35 hari. Pakan diberikan sesuai dengan kebutuhan pakan ayam arab. Pakan diberikan setiap pagi jam 07.00 dan sore hari jam 17.00. Air minum diberikan secara terus menerus (adlibitum) dan diganti setiap pagi hari.

c. Pengambilan data dan sampel

Pengambilan data penelitian dilakukan selama 35 hari untuk mengukur seluruh variabel penelitian. Adapun waktu pengambilan data yang dilakukan diuraikan sebagai berikut:

1. Pengambilan data konsumsi pakan, produksi telur, dan berat telur, dilakukan setiap pagi hari pukul 07.00 (sebelum diberi pakan).

2. Pengukuran konversi pakan dilakukan setiap 7 hari (1 minggu) sekali. Pengukuran konversi pakan dilakukan dengan cara menghitung jumlah pakan yang dikonsumsi dibagi dengan berat telur yang dihasilkan dalam waktu seminggu. 


\section{Rancangan Penelitian}

Penelitian ini didesain menggunakan Rancangan Acak Lengkap untuk menguji 4 (empat) perlakuan dan dilakukan dalam 4 (empat) ulangan, masing-masing ulangan terdiri atas 2 (dua) ekor ayam arab betina yang memiliki umur dan berat ayam yang sama. Ransum percobaan yang diuji adalah terdiri atas:

$\mathrm{P} 0=$ Ransum mengandung $0 \%$ Tepung daun Indigofera.

$\mathrm{P} 1=$ Ransum mengandung 10\% Tepung daun Indigofera.

$\mathrm{P} 2=$ Ransum mengandung 15\% Tepung daun Indigofera.

P3 = Ransum mengandung 20\% Tepung daun Indigofera.

Adapun model matematika rancangan acak lengkap sebagai berikut :

$\mathrm{Yij}=\mu+\tau_{\mathrm{i}+} \varepsilon_{\mathrm{ij}}$ (Steel dan Torrie, 1993).

Dimana:

Y $i j=$ Pengamatan pada baris (perlakuan) keI dan lajur (ulangan) ke-j

$\mu=$ rataan umum

$\tau_{\mathrm{i}}=$ pengaruh baris (perlakuan) ke-I $=\mu i-\mu$

$\varepsilon_{\mathrm{ij}}=$ pengaruh acak pada baris (perlakuan) ke-I, lajur (ulangan) ke-j

\section{Variabel Penelitian}

Variabel yang akan diamati pada penelitian ini adalah:

1. Konsumsi pakan

Konsumsi pakan merupakan jumlah pakan yang dimakan oleh ternak. Konsumsi pakan diukur dengan cara, jumlah berat pakan yang diberikan dikurangi dengan jumlah berat pakan sisa setiap sehari.

2. Berat telur

Berat telur dihitung dengan menimbang berat telur yang dihasilkan setiap hari menggunakan timbangan digital kapasitas $100 \mathrm{~g}$.

3. Konversi ransum

Konversi pakan merupakan perbandingan antara berat pakan yang dikonsumsi dengan berat telur yang dihasilkan.

4. Produksi telur harian

Produksi telur harian dihitung dengan membagi jumlah telur pada hari yang bersangkutan dengan jumlah ayam yang hidup pada hari yang sama dikali $100 \%$.

\section{Analisis Data}

Data hasil penelitian dianalisis menggunakan analisis ragam (ANOVA) berdasarkan RAL menggunakan standar SPSS. Apabila perlakuan berpengaruh nyata maka dilakukan uji lanjut dengan $U j i$ Duncan Multiple Range Test (Steel dan Torrie, 1993). Untuk mengevaluasi perbedaan antar perlakuan.

\section{HASIL DAN PEMBAHASAN}

\section{Konsumsi Pakan}

Rataan konsumsi ransum ayam arab yang diberi perlakuan pakan mengandung tepung daun Indigofera zollingeriana disajikan pada Tabel 3.

Tabel 3. Konsumsi pakan ayam arab (g/ekor/hari) yang diberi perlakuan tepung daun Indigofera zollingeriana yang berbeda pada pakan.

\begin{tabular}{ccccc}
\hline \multirow{2}{*}{ Ulangan } & \multicolumn{4}{c}{ Perlakuan } \\
\cline { 2 - 5 } & P0 & P1 & P2 & P3 \\
\hline 1 & 93,57 & 86,70 & 88,04 & 99,23 \\
2 & 90,61 & 89,43 & 91,50 & 82,22 \\
3 & 84,22 & 95,54 & 97,48 & 93,47 \\
4 & 95,34 & 89,56 & 94,16 & 92,17 \\
\hline Rata-rata & $90,93 \pm 4,89$ & $90,30 \pm 3,73$ & $92,79 \pm 4,01$ & $91,77 \pm 7,07$ \\
\hline
\end{tabular}


Hasil analisis ragam menunjukkan bahwa pemberian tepung daun Indigofera zollingeriana pada pakan tidak memberikan pengaruh nyata $(\mathrm{P}>0,05)$ terhadap tingkat konsumsi pakan. Data pada Tabel 3, menunjukan rataan konsumsi pakan ayam arab yang diberi tepung daun Indigofera zollingeriana yang dihasilkan yaitu: $\mathrm{P} 0$ $(90,93 \mathrm{~g} /$ ekor/hari $\pm 4,89), \quad \mathrm{P} 1 \quad(90,30$ g/ekor/hari $\pm 3,73), \quad$ P2 $(92,79$ g/ekor/hari $\pm 4,01)$, dan P3 $(91,77$ g/ekor/hari $\pm 7,07)$. Hasil penelitian ini sesuai dengan hasil yang dilaporkan oleh Pambudhi, (2003), bahwa jumlah konsumsi pakan ayam arab lebih sedikit dibandingkan ayam ras petelur yaitu 90-100 g/ekor/hari, sedangkan konsumsi ayam ras petelur mencapai 110-120 g/ekor/hari. Rendahnya konsumsi pakan ayam arab disebabkan karena ayam arab termasuk tipe ayam kecil, konsumsi pakan relatif lebih sedikit sehingga lebih efisien (Pambudhi, 2003).

Penyebab rendahnya konsumsi pakan ayam arab pada penelitian ini, selain ukuran ayam termasuk tipe ayam kecil, konsumsi pakan dipengaruhi oleh kandungan nutrien pakan, terutama kandungan energi metabolis. Tabel 2. menunjukkan bahwa energi metabolis pakan perlakuan mencapai $3.000 \quad \mathrm{kkal} / \mathrm{kg}$. Sementara energi metabolis yang dibutuhkan ayam arab yaitu $2700 \mathrm{kkal} / \mathrm{kg}$ (Yunus, 2013). Tingginya energi metabolis dalam pakan perlakuan dapat mempengaruhi konsumsi pakan ayam arab. Pendapat ini sesuai dengan pendapat Suprijatna (2005), yang melaporkan bahwa kandungan energi metabolis pakan menentukan banyaknya jumlah konsumsi pakan dan ayam mengkonsumsi pakan guna memenuhi kebutuhan energi, sehingga jika ayam mengkonsumsi pakan berenergi tinggi dan kebutuhan energinya telah terpenuhi maka ayam akan mengurangi bahkan menghentikan konsumsinya.
Hasil penelitian pemberian tepung daun Indigofera zollingeriana pada pakan, tidak memberikan pengaruh nyata terhadap konsumsi pakan ayam arab. Hasil penelitian ini sesuai dengan hasil penelitian yang dilakukan (Maharani et al, 2013), yang menyatakan bahwa pemberian 3, 6, dan 9\% Aspergillus microphylla tidak menyebabkan perbedaan konsumsi ransum pada ayam arab. Tidak adanya perbedaan yang nyata antara setiap perlakuan pada penelitian ini, kemungkinan dipengaruhi oleh kandungan nutrien pakan yang diberikan pada ayam arab. Tabel 2 menunjukan kandungan nutrien pakan perlakuan yang tidak memiliki perbedaan kandungan nutrien yang signifikan setiap perlakuan, sehingga perlakuan tidak mempengaruhi konsumsi pakan ayam arab.

Suprijatna (2005) menyatakan bahwa tingkat kandungan zat-zat makanan lain yang berada dalam ransum perlu disesuaikan dengan tingkat energi ransum. Karbohidrat, lemak, protein, dan zat-zat pembawa cita rasa dan aroma (flavor) yang akan diterima oleh sistem penerima adalah perangsang metabolit yang dapat menimbulkan perubahan selera makan secara fisik (Agustina dan Purwanti, 2012). Pada tembolok terdapat saraf yang berhubungan dengan pusat kenyang-lapar di hipotalamus, sehingga banyak sedikitnya ransum yang terdapat dalam tembolok akan memberikan respon terhadap saraf untuk makan atau menghentikan makan (Yuwanta, 2004).

\section{Berat Telur}

Rataan berat telur ayam arab yang diberi perlakuan pakan mengandung tepung daun Indigofera zollingeriana disajikan pada Tabel 4. 
Tabel 4. Berat telur ayam arab (g/ butir) yang diberi perlakuan tepung daun Indigofera zollingeriana yang berbeda pada pakan.

\begin{tabular}{ccccc}
\hline \multirow{2}{*}{ Ulangan } & \multicolumn{4}{c}{ Perlakuan } \\
\cline { 2 - 5 } & $\mathrm{P} 0$ & $\mathrm{P} 1$ & $\mathrm{P} 2$ & $\mathrm{P} 3$ \\
\hline 1 & 42,16 & 30,11 & 34,86 & 37,20 \\
2 & 38,23 & 33,45 & 40,02 & 35,27 \\
3 & 38,91 & 37,52 & 40,73 & 36,98 \\
4 & 36,25 & 28,00 & 37,36 & 36,55 \\
\hline Rata-rata & $38,89 \pm 2,46^{\text {a }}$ & $32,27 \pm 4,16^{\mathrm{b}}$ & $38,24 \pm 2,68^{\text {a }}$ & $36,50 \pm 0,86^{\text {ab }}$ \\
\hline
\end{tabular}

Keterangan: Nilai rataan yang diikuti superskrip huruf yang berbeda pada baris yang sama berbeda nyata $(\mathrm{P}<0,05)$.

Data pada Tabel 4 menunjukkan bahwa pemberian tepung daun Indigofera zollingeriana pada ransum memberikan pengaruh nyata $(\mathrm{P}<0,05)$ terhadap berat telur ayam arab. Perlakuan ransum yang diberi tepung daun Indigofera zollingeriana, menunjukkan bahwa ransum kontrol (P0) menghasilkan berat telur tertinggi yaitu $(38,84 \mathrm{~g} /$ butir $\pm 2,46)$, kemudian ransum yang diberi $15 \%$ tepung daun Indigofera zollingeriana (P2) yaitu $(38,24 \mathrm{~g} /$ butir $\pm 2,68$ ), selanjutnya ransum yang diberi $20 \%$ tepung daun Indigofera zollingeriana (P3) yaitu $(36,50 \mathrm{~g} /$ butir $\pm 0,86)$, dan ransum yang diberi $10 \%$ tepung daun Indigofera zollingeriana $(\mathrm{P} 1)$ menghasilkan berat telur terrendah yaitu $(32,27 \mathrm{~g} /$ butir $\pm 4,16)$. Data pada Tabel 5.2, menunjukkan bahwa perbedaan nyata terhadap berat telur yang diberi tepung daun Indigofera zollingeriana pada ransum terdapat pada perlakuan P0 dan perlakuan P2 lebih tinggi dari perlakuan P1. Berat telur perlakuan P1 berbeda tidak nyata dengan perlakuan $\mathrm{P} 3$, begitupun perlakuan P0 dan P2 berbeda tidak nyata dengan perlakuan $\mathrm{P} 3$.

Menurut Diwyanto dan Prijono (2007) berat telur ayam arab adalah 42,5 $\mathrm{g}$ butir. Berdasarkan hal tersebut, maka berat telur ayam arab pada hasil penelitian pemberian tepung daun Indigofera zollingeriana dalam ransum, untuk keseluruhan masih dibawah standar.
Rendahnya rataan bobot telur untuk setiap perlakuan kemungkinan dipengaruhi oleh kandungan protein dan asam amino yang berasal dari tepung daun Indigofera zollingeriana yang diberi dalam pakan yang kurang terserap oleh organ pencernaan ayam arab. Latifah (2007), menyatakan bahwa besar kecilnya ukuran telur unggas sangat dipengaruhi oleh kandungan protein dan asam-asam amino dalam ransum. Amrullah (2003) menyatakan bahwa, metionin merupakan asam amino essensial kritis yang sangat berpengaruh terhadap bobot telur, mengingat bahwa lebih dari $50 \%$ berat kering telur adalah protein.

\section{Konversi Pakan}

Rataan konversi pakan ayam arab yang diberi perlakuan pakan mengandung tepung daun Indigofera zollingeriana disajikan pada Tabel 5. 
Tabel 5. Konversi pakan ayam arab yang diberi tepung daun Indigofera zollingeriana

\begin{tabular}{ccccc}
\hline \multirow{2}{*}{ Ulangan } & \multicolumn{4}{c}{ Perlakuan } \\
\cline { 2 - 5 } & $\mathrm{P} 0$ & $\mathrm{P} 1$ & $\mathrm{P} 2$ & $\mathrm{P} 3$ \\
\hline 1 & 2,22 & 2,88 & 2,53 & 2,67 \\
2 & 2,37 & 2,67 & 2,29 & 2,33 \\
3 & 2,16 & 2,55 & 2,39 & 2,53 \\
4 & 2,63 & 3,20 & 2,52 & 2,52 \\
\hline Rata-rata & $2,35 \pm 0,21^{\mathrm{b}}$ & $2,82 \pm 0,28^{\mathrm{a}}$ & $2,43 \pm 0,11^{\mathrm{b}}$ & $2,51 \pm 0,14^{\mathrm{b}}$ \\
\hline
\end{tabular}

Keterangan: Nilai rataan yang diikuti superskrip huruf yang berbeda pada baris yang sama berbeda nyata $(\mathrm{P}<0,05)$

Data pada Tabel 5 menunjukkan pemberian tepung daun Indigofera zollingeriana pada pakan memberikan pengaruh nyata $(\mathrm{P}<0,05)$ terhadap konversi pakan ayam arab. Perlakuan pakan P1 menghasilkan nilai konversi pakan tertinggi yaitu $(2,82 \pm 0,28)$, kemudian pakan yang diberi tepung daun Indigofera zollingeriana sebanyak 20\% menghasilkan konversi pakan yaitu $(2,51 \pm 0,14)$, selanjutnya pakan yang diberi daun Indigofera zollingeriana sebanyak 15\% menghasilkan konversi pakan yaitu $(2,43 \pm 0,11)$ dan pakan kontrol menghasilkan konversi pakan terrendah yaitu $(2,35 \pm 0,21)$.

Data Tabel 5 menunjukkan bahwa perbedaan nyata terhadap konversi pakan yang diberi tepung daun Indigofera zollingeriana pada pakan terdapat pada perlakuan P0, P2, dan P3 terhadap P1 yang nilai konversi pakannya lebih tinggi. Konversi pakan perlakuan P0 tidak berbeda nyata dengan perlakuan P2 dan P3. Terjadinya perbedaan yang nyata antara perlakuan P1 terhadap perlakuan P0, P2, dan $\mathrm{P}$ 3, dipengaruhi oleh konsumsi pakan yang tinggi tetapi berat telur rendah. Kemampuan ternak mengubah pakan menjadi daging dan telur erat kaitannya dengan angka konversi pakan. Faktor yang mempengaruhi angka konversi ransum adalah produksi telur, kandungan nutrien ransum, bobot telur dan suhu lingkungan.

Konversi pakan erat kaitannya dengan konsumsi pakan dan produksi telur (Puspita, 2008). Semakin rendah nilai konversi pakan yang diperoleh, maka semakin efisien ternak, selain jumlah pakan yang dikonsumsi dengan berat telur yang dihasilkan, Anggorodi (1994) menjelaskan bahwa tinggi rendahnya konversi pakan sangat ditentukan oleh keseimbangan antara energi metabolisme dengan zat-zat nutrisi terutama protein dan asam-asam amino.

Kualitas protein Indigofera zollingeriana ditentukan oleh komposisi asam amino esensialnya (Abdullah et al, 2010). Nilai indeks asam amino esensial Indigofera zollingeriana adalah 21,45\% lebih rendah dibandingkan asam amino bungkil kedelai 36.34\% (Palupi et al, 2014). Tabel 5.3, menujukan bahwa rataan antara perlakuan P1 dan perlakuan P2 dan P3 mengalami penurunan angka konversi pakan. Penurunan angka konversi pakan disebabkan karena tepung daun Indigofera zollingeriana yang digunakan dalam pakan mengandung tanin sebanyak $0,06-0,22 \%$ dan saponin sebanyak 1,66-6,16\% dalam jumlah relatif rendah (Herdiawan et al, 2014). Menurut Kumar et al (2005) toleransi tanin dalam pakan unggas sebanyak $2.6 \mathrm{~g} / \mathrm{kg}$, sementara untuk saponin $3.79 \mathrm{~g} / \mathrm{kg}$. Hasil penelitian ini menunjukan bahwa penambahan tepung daun Indigofera zollingeriana tidak mengganggu kualitas pakan ayam arab, meski kadar saponin yang terkandung pada daun Indigofera zollingeriana melebihi kadar toleransi pemberian saponin pada unggas. 
Produksi Telur Harian

Rataan produksi telur harian ayam
arab yang diberi perlakuan pakan mengandung tepung daun Indigofera zollingeriana disajikan pada Tabel 6.

Tabel 6. Produksi telur harian ayam arab (\%) yang diberi perlakuan tepung daun Indigofera zollingeriana pada pakan.

\begin{tabular}{ccccc}
\hline \multirow{2}{*}{ Ulangan } & \multicolumn{4}{c}{ Perlakuan } \\
\cline { 2 - 5 } & P0 & P1 & P2 & P3 \\
\hline 1 & 76,79 & 48,21 & 71,43 & 80,36 \\
2 & 91,07 & 78,57 & 94,64 & 67,86 \\
3 & 69,64 & 85,71 & 87,50 & 64,29 \\
4 & 89,29 & 42,86 & 75,00 & 64,29 \\
\hline Rata-rata & $81,70 \pm 10,25$ & $63,84 \pm 21,45$ & $82,14 \pm 10,81$ & $69,20 \pm 7,63$ \\
\hline
\end{tabular}

Data pada Tabel 5.4, menunjukkan bahwa pemberian tepung daun Indigofera zollingeriana pada pakan tidak memberikan pengaruh nyata $(\mathrm{P}>0,05)$ terhadap produksi telur harian ayam arab. Perlakuan pakan yang diberi tepung daun Indigofera zollingeriana menghasilkan produksi telur harian berturut-turut yaitu: perlakuan P0 $(81,70 \% \pm 10,25), \quad \mathrm{P} 1(63,84 \% \pm 21,45), \quad \mathrm{P} 2$ $(82,14 \% \pm 10,81)$, dan P3 $(69,20 \% \pm 7,63)$. Hasil penelitian ini sesuai dengan penelitian Natalia et al, (2005) dan Sulandari et al, (2007), dimana produksi telur ayam arab berkisar 190-250 butir/ tahun yang berarti nilai henday production ayam arab sebesar (68-79\%). Selain pendapat Natalia et al, (2005) dan Sulandari et al, (2007), Mulyadi (2013) melaporkan bahwa pemberian pakan fungsional yang mengandung probiotik lactobacillus dan minyak ikan lemuru tidak berpengaruh nyata $(\mathrm{P}>0,05)$ terhadap performa produksi (konsumsi pakan, konsumsi protein, konsumsi lemak, konsumsi energi, produksi telur dan konversi pakan) ayam arab.

Daun Indigofera zollingeriana segar sangat disukai unggas itik dan dalam bentuk tepung digunakan untuk puyuh dan ayam buras, pada puyuh penggunaan tepung daun Indigofera zollingeriana sampai dengan $10 \%$ tidak berdampak pada produksi telur selama 2 bulan produksi pertama
(Akbarillah et al, 2010). Hasil penelitian ini tidak memberikan perbedaan yang nyata terhadap produksi harian telur ayam arab. Hal ini disebabkan karena performan produksi dipengaruhi oleh konsumsi lemak, konsumsi protein, konsumsi energi dan serat kasar pada ransum, yang mempengaruhi produksi telur harian ayam arab. Persentase produksi pada saat periode produksi nyata dipengaruhi oleh taraf protein selama periode produksi (Suprijatna, 2005). Hal ini sejalan dengan laporan Agustina (2013), bahwa untuk memproduksi telur atau daging yang tinggi, dalam pakan harus tersedia : protein, energi (karbohidrat dan lemak), vitamin, mineral dan air.

Produksi telur yang relatif sama pada setiap perlakuan selain disebabkan oleh pakan juga disebabkan oleh genetik ayam arab. Pendapat ini sesuai dengan Widjaja dan Abdullah (2002), bahwa ayam arab dapat berproduksi secara maksimal dipengaruhi oleh faktor dalam (keturunan) dan faktor luar seperti makanan. Gultom et al. (1989) melaporkan bahwa faktor penting yang harus diperhatikan dalam formulasi ransum ayam adalah kebutuhan protein, energi, serat kasar, Ca dan P. Secara genetis tiap jenis unggas mempunyai batas kemampuan maksimal dalam berproduksi, dalam kondisi lingkungan yang baik dan sesuai dengan yang dibutuhkan. Sehingga 
lingkungan yang baik belum tentu yang dibutuhkan oleh unggas tertentu, maka produksi telur akan sampai pada kemampuan produksi menurut genetisnya (Rasyaf, 1991).

\section{KESIMPULAN}

Berdasarkan hasil penelitian dapat disimpulkan bahwa tepung daun Indigofera zollingeriana dapat mempengaruhi berat telur ayam arab dan konversi pakan ayam arab. Namun tepung daun Indigofera zollingeriana tidak mempengaruhi konsumsi pakan ayam arab dan produksi telur harian ayam arab

\section{DAFTAR PUSTAKA}

Abdullah, L., N.R. Kumalasari. Nahrowi. dan Suharlina. 2010. Pengembangan produk hay, tepung dan pelet daun Indigofera $s p$ sebagai alternative sumber protein murah pakan kambing perah. Laporan Penelitian Hibah Insentif. Fakultas Peternakan IPB.

Abdullah, L. 2010. Pengembangan produk hay, tepung dan pellet daun Indigofera cordifolia sebagai alternatif sumber protein murah pakan kambing perah. Laporan Akhir Program Intensif Terapan LPPM. IPB.

Agustina, L dan S. Purwanti. 2012. Ilmu Nutrisi Unggas. Rumah Pengetahuan. Solo.

Agustina, L . 2013. Potensi Ayam Buras Indonesia. Graha Ilmu. Yogyakarta.

Akbarillah, T, Kususiyah, dan Hidayat. 2010. Pengaruh penggunaan daun indigofera segar sebagai suplemen pakan terhadap produksi dan warna yolk itik. Sains Peternakan. Indonesia. 5 (1)

Amrullah, I. K. 2003. Nutrisi Ayam Petelur. Lembaga Satu Gunung Budi, Bogor.
Diwyanto, K. dan S.N. Prijono. 2007. Keanekaragaman Sumber Daya Hayati Ayam Lokal Indonesia. Pusat Penelitian Biologi Lembaga Ilmu Pengetahuan Indonesia, Jakarta.

Faradillah, F. 2015. Penggunaan tepung pucuk Indigofera zollingeriana sebagai substitusi bungkil kedelai dalam ransum terhadap produktivitas dan aspek kesehatan puyuh. Pascasarjana Institut Pertanian Bogor. Bogor.

Gultom, D., Wiloeto. D. dan Primasari, 1989. Protein dan energi rendah dalam ransum ayam buras periode bertelur. Prosiding Seminar Nasional Tentang Unggas Lokal. Fakultas Peternakan UNDIP. Semarang.

Herdiawan I, L. Abdullah , D Sopandi. 2014. Status Nutrisi Hijauan Indigofera zollingeriana pada Berbagai Taraf Perlakuan Stres Kekeringan dan Interval Pemangkasan. JITV. 19 (2) :91-103

Kumar, V., A.V. Elangovan, dan A.B. Mandal. 2005. Utilization of reconstituted high tannin sorgum in the diets of broiler chickens. Asian-Aust. J of Anim Sci. 18: 538-544.

Latifah, R. 2007. The Increasing of Afkir Duck's Egg Quality With Pregnant Mare's Serum Gonadotropin (Pmsg) Hormones. The way to increase of layer duck. 4:1-8.

Leeson, S. and J. D. Summers. 1982. Use of single-stage low protein diet for growing Leghorn pullets. Poultry. Sci. 61: 1684-1691.

Maharani, P., N. Suthama dan H. I. Wahyuni. 2013. Massa kalsium dan protein daging pada ayam arab petelur yang diberi ransum menggunakan Azolla microphylla. Journal Animal Agriculture. Fakultas Peternakan dan Pertanian Universitas Diponegoro Semarang. 2 (1):18-27. 
Mulyadi, Y. 2013. Penggunaan Pakan Fungsional terhadap Performan Produksi dan Kualitas Telur Ayam Arab. Jurnal ilmu ternak. 13 (2)

Natalia, H., D. Nista, Sunarto \& D.S Yuni. 2005. Pengembangan Ayam Arab. Balai Pembibitan Ternak Unggul Sembawa. Balai Pembibitan Ternak Unggul (BPTU) Sapi Dwiguna dan Ayam Sembawa, Palembang.

Palupi R, Abdullah. L, Astuti DA, Sumiati. 2014. Potensi dan pemanfaatan tepung pucuk Indigofera sp. sebagai bahan pakan substitusi bungkil kedelai dalam ransum ayam petelur. JITV 19 (3) : 210-219.

Pambudhi. 2003. Beternak ayam arab merah si tukang bertelur. Agromedia Pustaka. Jakarta.

Puspita. 2008. Performa ayam ras petelur periode produksi yang diberi ransum rendah kalsium dengan penambahan zeolit. Skripsi. Fakultas Peternakan, Institut Pertanian Bogor.

Rasyaf, M. 1991. Memelihara Ayam Ras. Penebar Swadaya. Jakarta.

Steel, R.G.D dan J.H. Torrie. 1991. Prinsip dan prosedur statistik suatu pendekatan biometrik. Terjemahan oleh B, Sumantri. Gramedia Pustaka Utama. Jakarta.

Sulandari, S., M.S.A. Zein, S. Paryanti, T. Sartika, M. Astuti, T. Widjastuti, E. Sujana, S. Darana, I. Setiawan dan D. Garnida. 2007. Sumber genetik ayam lokal Indonesia dan keanekaragaman sumber daya hayati ayam lokal Indonesia. Lembaga Ilmu Pengetahuan Indonesia Press. Jakarta. Halm. 45-104.

Suprijatna, E. 2005. Pengaruh protein ransum saat periode pertumbuhan terhadap performans produksi telur saat periode produksi pada ayam ras petelur tipe medium. J. Indon.Trop.Anim.Agric.

Widjaja, K. Dan S. Abdullah. 2002. Peluang Bisnis Ayam Ras dan Buras. Penebar Swadaya. Jakarta

Yunus, A. 2013. Meraup untung budidaya ayam arab. Penerbit Pustaka Baru Press. Yogyakarta.

Yuwanta, T. 2004. Dasar Ternak Unggas. Kanisius. Yogyakarta. 